\title{
MENINGKATKAN KEMAMPUAN MENGENAL LAMBANG HURUF MELALUI MEDIA KARPET HURUF PADA KELOMPOK A DI TK MEKAR SARI TENGGARONG SEBERANG
}

\author{
Tarsiyem \\ PG PAUD, FKIP, Universitas Widya Gama Mahakam Samarinda \\ ( umysudarwati@gmail.co.id) \\ Hanita \\ PG PAUD, FKIP, Universitas Widya Gama Mahakam Samarinda \\ (nitahanita87@gmail.com)
}

\begin{abstract}
From sixteen students in group A of Mekar Sari Kindergarten Tenggarong Seberang, only two of them recognized letters. Therefore, the researcher conducted a classroom action research to improve students' ability in recognizing symbols of letters by using letter mat. This study applied two cycle wherein each cycle consists of palnning, implementation, observation and reflection. To gather the data, the researcher employed observation. Meanwhile, to analyze the data, the researcher applied percentage analysis. As the research subjects, the researcher involved sixteen students, consisting of seven males and nine females.

At the first cycle, $68,75 \%$ students were able to repeat the symbols of letters the teacher mentioned. $68,75 \%$ students managed to mention the letter symbols. $62,5 \%$ students managed to mention the letters of their own names. $68,75 \%$ students were able to mention the letter symbol which teacher mentioned. In other words, in the first cycle, 68,75\% students managed to recognize symbols of letter. Moreover, at the second cycle, $100 \%$ students were able to repeat the symbols of letters the teacher mentioned. $100 \%$ students managed to mention the symbols letter symbols. $87,5 \%$ students managed to mention the mention the letters of their own names. $100 \%$ students were able to mention the letter symbol which teacher mentioned. It can be concluded that $97,5 \%$ students successfully recognized the symbols of letters and were considered able to develop well.

In brief, learning letter through letter mat has effectively increased students' ability in recognizing symbols of letters, especially in group A at Mekar Sari Kindergarten Tenggarong Seberang. Therefore, it is recommended for teachers to use the letter mat for teaching letters.
\end{abstract}

Key Words : Symbols of letter, letter mat

\section{PENDAHULUAN}

Dunia anak-anak itu unik, penuh kejutan, dinamik, serta ingin selalu mengekplorasi, dunia bermain dan belajar, selalu berkembang seiring dengan perkembangan dan pertumbuhan anak-anak itu sendiri,dunia yang penuh warna maka akan banyak suka dan duka dalam menghadapi tingkah polah anakanak.

Menurut Undang-Undang Perlindungan Anak-anak mempunyai hak tumbuh dan berkembang, bermain, beristirahat, berkreasi dan belajar dalam suatu pendidikan. Jadi, belajar adalah hak anak, bukan kewajiban orang tua 
dan pemerintah wajib menyediakan sarana dan prasarana pendidikan untuk anak dalam rangka program belajar. Karena belajar adalah hak, maka belajar harus menyenangkan, kondusif dan memungkinkan anak menjadi termotivasi dan antusias. Jadi, memaksa anak untuk belajar, sehingga anak merasa tertekan atau membiarkan anak tidak mendapatkan pendidikan yang layak adalah tindakan kekerasan. Perlu dipahami belajar pada anak usia dini bukan berorientasi untuk mengejar prestasi, seperti kemampuan membaca, menulis, berhitung dan pengusaan pengetahuan lain yang sifatnya akademis. Orientasi belajar pada anak usia dini yang sesungguhnya adalah mengembangkan rasa senang untuk belajar mencari tahu, mencoba, membuat gagasan, menemukan, menggunakan segala hal yang ada di sekitarnya (Direktorat PAUD, 2010a:3) Susanto (2011:2) menyatakan bahwa selain memahami bahwa anak merupakan individu yang unik, ada beberapa catatan yang perlu diperhatikan dalam kaitannya dalam upaya memahami anak, yaitu bahwa anak adalah anak, bukan orang dewasa. Anak adalah anak-anak, bukan orang dewasa dalam ukuran mini. Anak adalah anak Karena itu, anak haruslah diperlukan dan dipahami sebagai individu yang sedang tumbuh dan berkembang. Mereka juga memiliki dunia sendiri yang khas dan harus dilihat dengan kacamata anak-anak. Untuk itu dalam menghadapi mereka dibutuhkan adanya kesabaran, pengertian serta toleransi yang mendalam. Dunia anak adalah dunia bermain, yaitu dunia yang penuh semangat apabila terkait dengan suasana yang menyenangkan. Maka selayaknya konsep pendidikan untuk usia dini dirancang dalam bentuk bermain. Intinya, bermain adalah belajar dan belajar adalah bermain. Anak belajar melalui bermain, bermain yang menyenangkan (Soendari, 2010:11).

Salah satu tingkat pencapaian perkembangan yang sangat penting bagi anak usia dini Permendiknas No.58 tahun 2009 adalah mengenal lambang huruf. Hal ini penting sekali karena mengenal huruf merupakan pengetahuan dasar bagi anak sehingga anak mampu mengenal tulisan dan kata yang ada disekitarnya. Mengenal lambang huruf juga sangat penting bagi anak dalam mendukung perkembangan bahasa terutama pada lingkup perkembangan keaksaraan (Permendiknas, 2009:10).

Mengenal huruf dalam teori whole language dalam Susanto (2011:86) yaitu mengenal huruf dan bunyi dari konteksnya (dari bahasa yang digunakan).Misalnya guru bertanya sama anak, siapa namanya,anak menjawab "Ani” kemudian guru 
bertanya lagi bunyi apa yang kamu kenal dari namamu? Lalu anak mulai mengindentifikasi bunyi dan huruf a dan ni (n dan i ) jadi anak belajar dari konsep ke parsial. Adapun manfaat pengenalan huruf bagi anak adalah: a) meningkatkan kemampuan anak dalam mengenal huruf dan menguraikan menjadi kata, b)Meningkatkan kualitas pada pembelajaran berbahasa anak terutama dalam pengenalan huruf sehingga nantinya anak tidak mengalami kesulitan dalam mengembangkan kompetensi berbahasa khusunya pada kompetensi menulis, c) Mengembangkan ide-ide dan karya inovatif bagi anak, menambah wawasan dan pengetahuan anak sejak dini.

Dengan mengenal huruf akan mempermudah anak untuk mengenal tulisan, dan akan mempermudah anak dalam membaca dan berbicara. Dengan mengenal huruf akan berdampak pada kehidupan social anak, anak akan dapat bersosialisasi dengan tutur bahasa yang baik karena perkembangan bahasanya sudah baik, seain itu dapat meningkatkan prestasi belajar anak disekolah.

Pembelajaran pengenalan huruf tidak bisa dilepaskan dari aktivitas bermain. Alasannya bagi anak bermain bukan hanya menjadi kesenangan tetapi juga suatu kebutuhan yang mau tidak mau harus terpenuhi. Jika tidak menurut
Conny R, Semiawan dalam Tadkiroatun Musfiroh (2005: 1) ada satu tahapan perkembangan yang berfungsi kurang baik yang akan terlihat kelak jika si anak sudah menjadi remaja. Catron dan Allen dalam Tadkiroatun Musfiroh (2005: 1) menambahkan bahwa bermain merupakan Wahana yang memungkinkan anak-anak berkembang optimal. Bermain secara langsung mempengaruhi seluruh wilayah dan aspek perkembangan anak termasuk pengembangan bahasa.

Kegiatan bermain menggunakan karpet huruf adalah kegiatan bermain yang menggunakan media karpet segi empat berukuran panjang satu meter dan lebar satu meter, dan dalam karpet tersebut terdapat lambang huruf abjad dan gambar-gambar. Kegiatan ini dilakukan dengan cara menggunakan anggota fisik untuk berlari menuju huruf pada setiap huruf yang ditunjukan pada anak. Misalnya guru mengambil gulungan kertas yang sudah bertuliskan huruf di dalam wadah kemudian membuka di depan hadapan para siswa dan anak berlomba berlari menuju huruf tersebut untuk berdiri diatas huruf tersebut.

Pada dasarnya terdapat berbagai macam jenis karpet huruf misalnya seperti puzzle huruf, dengan bermain karpet huruf anak dapat mengenal huruf, menyebutkan huruf dan merangkai 
huruf dengan begitu bermain karpet huruf ini diharapkan dapat menambah kosakata huruf anak dan dapat meningkatkan aspek perkembangan bahasa anak.

Pada PTK saya ini saya menggunakan karpet huruf buatan saya sendiri yang terdiri dari bahan-bahan sederhan yaitu: a) karpet, b) gambar lambang huruf, c) gunting, d) lakban, e) spidol warna. Cara membuatnya adalah sediakan karpet berukuran panjang dan lebar satu meter kemudian temple karpet menggunakan gambar lambang huruf menggunakan lakban.

Seperti permasalahan yang sering terjadi di TK Mekar Sari adalah dari 14 orang siswa, hanya 5 orang anak yang mengerti huruf. Selebihnya anak mampu menyebutkan kata namun ketika ditanya huruf yang apa saja yang terdapat pada kata yang disebutkan anak-anak belum mengerti, contoh anak-anak dapat menyebutkan nama mereka tetapi ketika ditanya huruf apa saja dalam nama mereka anak-anak belum dapat menjawabnya. Sehingga dapat dikatakan perkembangan bahasa pada siswa yang berada di TK Mekar Sari masih rendah.

Berdasarkan uraian diatas tersebut menjadi permasalahan dikelas saya, dan saya selaku peneliti harus mencari jalan keluar untuk menyelesaikan masalah yang berkaitan dengan aspek perkembangan bahasa anak yaitu dengan bermain huruf menggunakan media karpet huruf, dan untuk memperbaiki permasalahan peneliti akan melakukan PTK karena masalah tersebut peneliti mengangkat judul “ Meningkatkan kemampuan mengenal lambang huruf melalui media karpet huruf pada kelompok A di TK Mekar Sari Tenggarong Seberang ”.

\section{METODOLOGI PENELITIAN}

\section{Desain Penelitian}

Penelitian ini peneliti menggunakan Penelitian Tindakan Kelas yang akan dilaksanakan di TK Mekar Sari Desa Suka Maju Tenggarong Seberang. Peneliti akan bekerja sama dengan guru kelas disekolah tersebut. Penelitian tindakan kelas ini termasuk penelitian Kuantitatif. Penelitian tindakan kelas adalah suatu kegiatan penelitian dengan mencermati sebuah kegiatan belajar yang diberikan tindakan, yang sengaja dimunculkan kedalam sebuah kelas, yang bertujuan memecahkan masalah atau meningkatkan mutu pembelajaran dikelas tersebut. Tindakan yang secara sengaja dimunculkan. Dari pengertian ini, maka dapat dipahami bahwa PTK sebenarnya disebut dengan penelitian tindakan kelas (action research) yang mengambil subyek penelitiannya di kelas. Dalam penelitian pendidikan action research tidak hanya terbatas 
dengan ruang kelas saja, melainkan dimana saja guru mengajar atau bekerja. PTK dapat didefinisikan sebagai sebuah tindakan yang dilakukan secara siklus, dalam rangka memecahkan masalah, sampai terpecahkan. Penelitian Tindakan Kelas dilaksanakan melalui serangkaian siklus meliputi : (a) Perencanaan, (b) Pelaksanaan,(c) pengamatan, (d) perefleksian.

\section{Subyek dan objek penelitian}

Subyek penelitian adalah siswa TK Mekar Sari, siswa mengenal berbagai macam lambang huruf melalui media karpet huruf pada kelompok B TK Mekar Sari Desa Suka Maju Kecamatan Tenggarong Seberang tahun ajaran 2016/2017 yang berjumlah 16 orang anak terdiri dari, 9 orang anak laki-laki dan 7 orang anak perempuan. Objek dalam penelitian ini adalah bermain huruf menggunakan karpet huruf, karena dengan bermain karpet huruf dapat meningkatkan kemampuan mengenal huruf dan akan membuat perkembangan aspek bahasa anak semakin meningkat.

\section{Prosedur Penelitian}

Prosedur penelitin adalah langkah-langkah yang digunakan sebagai alat untuk mengumpulkan data dan menjawab pertanyaan-pertanyaan dalam penelitian. Didalam prosedur penelitian ini penulis membahas tentang metode dan teknik pengumpulan data.

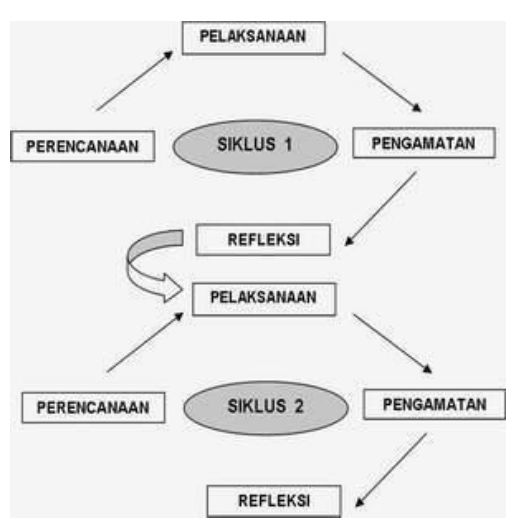

Gambar 3.1

Siklus Penelitian Tindakan Kelas Menurut Kurt Lewin (Arikunto, 2010:96)

\section{Rangkaian perencanaan Siklus}

Perencanaan Siklus seperti :

a. Mengidentifisikasi masalah

b. Menyiapkan materi pembelajaran

c. Menyiapkan media

d. Menyiapkan alat evaluasi

Pelaksanaan tindakan siklus seperti :

a. Melakukan opening pagi

b. Menyampaikan Pembelajaran

c. Penutup

Pengamatan Siklus seperti:

Mengamati kebiasaan-kebiasaan anak dalam belajar dan mencatat setiap peristiwa yang terjadi saat melaksanakan PTK agar dapat memperoleh da Refleksi Siklus Seperti:

Melakukan evaluasi kegiatan untuk mengemukakan kembali apa yang sudah dilakukan sesuai dengan perencanaan, pelaksanaan dan pengamatan. 


\section{Teknik Pengumpulan data}

Tehnik Pengumpulan data Tehnik dan instrumen pengumpulan data dalam rangka mendukung penelitian, maka data diperoleh melalui prosedur sebagai berikut : Observasi Dalam penelitian ini dilakukan pengamatan langsung terhadap peran guru dalam pengembangan kemampuan mengenal berbagai lambang huruf dan mencatat data atau informasi yang diperlukan dan dibutuhkan sesuai dengan masalah yang diteliti. Observasi merupakan proses pengambilan data dalam penelitian dimana peneliti atau pengamat melihat situasi penelitian. Teknik ini digunakan untuk mengamati dari dekat dalam upaya mencari dan menggali data melalui pengamatan secara langsung dan mendalam terhadap subyek dan objek yang diteliti.

\section{Teknis Analisis data}

Tehnik Analisis Data Menurut Sugiono (2011:15), metode penelitian kuantitatif adalah metode penelitian yang digunakan untuk meneliti pada kondisi obyek yang alamiah, di mana peneliti sebagai instrumen kunci. Pada penelitian kuantitatif peneliti berinteraksi secara langsung dengan subjek yang diteliti serta dapat mengamati mereka dari awal sampai akhir proses penelitian. Dalam penelitian kuantitatif, peneliti ikut berpartisipasi di lapangan. Pada intinya
Penelitian Tindakan Kelas (PTK) bertujuan untuk memperbaiki persoalan nyata dalam mengembangkan kemampuan mengenal berbagai macam lambang huruf melalui media karpet huruf yang dialami langsung dalam interaksi antara pendidik dengan anak yang sedang belajar. PTK ini datanya dianalisis dengan melihat kecenderungan umum, selain itu digunakan juga analisis kuantitatif dengan rumus :

$P=(F / N) \times 100 \%$

Keterangan :

$\mathrm{P}$ : Presentase

F : Frekuensi dari setiap jawaban

$\mathrm{N}$ : Jumlah responden

\section{Indikator Keberhasilan}

Indikator keberhasilan terpenuhi jika anak sudah mencapai tahap perkembangan $\quad 90 \%$ dari jumlah keseluruhan siwa. Dari 16 orang siswa berarti 14 anak yang sudah memenuhi indicator yang ditentukan.

\section{PEMBAHASAN}

\section{Siklus I}

Adapun hasil observasi upaya meningkatkan kemampuan mengenal lambang huruf pada siklus I dapat dilihat pada lembar observasi ( data terlampir). Dari hasil pengamatan siklus I dapat diketahui pada aspek mampu menyebutkan lambang huruf pada namanya sendiri, yaitu terdapat 6 anak 
(37,5\%) dengan kategori mulai berkembang, 4 anak (25\%) dengan kategori berkembang sesuai harapan, dan 6 anak (37,5\%) dengan kategori berkembang sangat baik. Dapat menyebutkan lambang huruf terdapat 4 anak (25\%) dengan kategori mulai berkembang, 5 anak $(31,25 \%)$ dengan kategori berkembang sesuai harapan, dan 7 anak $(43,75 \%)$ dengan kategori berkembang sangat baik. Dapat mengulang kembali lambang huruf yang disebutkan oleh guru terdapat 5 anak $(31,25 \%)$ dengan kategori mulai berkembang, 5 anak $(31,25 \%)$ dengan kategori berkembang sesuai harapan dan 7 anak (43,75\%) dengan kategori berkembang sangat baik. Dapat menyebut kata-kata ayng berlambang huruf sama dengan yang disebutkan guru, terdapat 5 anak $(31,25 \%)$ dengan kategori mulai berkembang, 6 anak $(37,5 \%)$ dengan kategori berkembang sesuai harapan dan 5 anak $(31,25 \%)$ dengan kategori berkembang sangat baik.

Berdasarkan hasil pengamatan siklus I, kemampuan mengenal lambang huruf melalui media karpet huruf jika dibangdingkan dengan sebelum melakukan tindakan. Hal ini dapat dilihat pada tabel berikut ini :
Tabel .1

Kemampuan Mengenal Lambang Huruf Siklus I

\begin{tabular}{|c|c|c|c|c|c|c|c|}
\hline \multirow{2}{*}{$\begin{array}{c}\text { No } \\
\text {. }\end{array}$} & \multirow{2}{*}{$\begin{array}{l}\text { Aspek yang } \\
\text { diobservasi }\end{array}$} & \multicolumn{4}{|c|}{$\begin{array}{c}\text { Hasil } \\
\text { pengamatan }\end{array}$} & \multirow{2}{*}{$\begin{array}{c}\text { Jumla } \\
\mathrm{h} \\
\text { yang } \\
\text { tuntas }\end{array}$} & \multirow{2}{*}{$\begin{array}{c}\text { per } \\
\text { sen } \\
\text { tas } \\
\text { e }\end{array}$} \\
\hline & & $\begin{array}{l}\mathrm{B} \\
\mathrm{B}\end{array}$ & $\begin{array}{l}\mathrm{M} \\
\mathrm{B}\end{array}$ & $\begin{array}{l}\mathrm{B} \\
\mathrm{S} \\
\mathrm{H}\end{array}$ & $\begin{array}{l}\text { B } \\
\text { S } \\
\text { B }\end{array}$ & & \\
\hline 1. & $\begin{array}{c}\text { Dapat } \\
\text { mengulang } \\
\text { kembali } \\
\text { lambang huruf } \\
\text { yang disebutkan } \\
\text { guru }\end{array}$ & 0 & 4 & 6 & 4 & 10 & $\begin{array}{l}62, \\
5 \%\end{array}$ \\
\hline 2. & $\begin{array}{c}\text { Dapat } \\
\text { menyebutkan } \\
\text { lambang huruf } \\
\text { yang } \\
\text { ditunjukkan oleh } \\
\text { guru } \\
\end{array}$ & 0 & 4 & 5 & 7 & 12 & $\begin{array}{l}75 \\
\%\end{array}$ \\
\hline 3. & $\begin{array}{c}\text { Dapat } \\
\text { menyebutkan } \\
\text { lambang huruf }\end{array}$ & 0 & 5 & 5 & 6 & 11 & $\begin{array}{l}68, \\
75 \\
\%\end{array}$ \\
\hline 4. & $\begin{array}{l}\text { Anak mampu } \\
\text { menyebutkan } \\
\text { lambang huruf } \\
\text { pada namanya } \\
\text { sendiri } \\
\end{array}$ & 0 & 5 & 4 & 7 & 11 & $\begin{array}{l}68, \\
75 \\
\%\end{array}$ \\
\hline 5. & $\begin{array}{c}\text { Dapat } \\
\text { menyebutkan } \\
\text { kata yang } \\
\text { berlambang } \\
\text { huruf sama } \\
\text { dengan yang } \\
\text { disebutkan oleh } \\
\text { guru } \\
\end{array}$ & 0 & 5 & 6 & 5 & 11 & $\begin{array}{l}68, \\
75 \\
\%\end{array}$ \\
\hline & $\begin{array}{l}\text { umlah rata-rata } \\
\text { ketuntasan }\end{array}$ & $\begin{array}{l}0 \\
\%\end{array}$ & \begin{tabular}{l|}
3 \\
1 \\
2 \\
2 \\
5 \\
$\%$ \\
\end{tabular} & $\begin{array}{l}3 \\
6 \\
2 \\
2 \\
5 \\
\% \\
\end{array}$ & \begin{tabular}{l|}
3 \\
8 \\
\\
7 \\
5 \\
$\%$ \\
\end{tabular} & 68,7 & \\
\hline
\end{tabular}

Hasil pengamatan siklus I berdasarkan tabel 4.2, kemampuan mengenal lambang huruf yaitu : dapat mengulang kembali lambang huruf yang disebutkan guru 62,5\%, dapat menyebutkan lambang huruf yang ditunjukkan oleh guru $75 \%$, dapat menyebutkan lambang huruf 68,75\%, anak mampu menyebutkan lambang huruf pada namanya sendiri 68,75\%, anak mampu menyebutkan kata yang berlambang huruf sama dengan yang disebutkan oleh guru 68,75\%. Maka nilai keberhasilan pada siklus I adalah $68,75 \%$. Kemampuan mengenal 
lambang huruf pada siklus I meningkat dengan kemampuan anak pada pra siklus.Karena nilai keberhasilan pada siklus I belum mencapai batas minimal pada penelitian, maka penelitian berlanjut pada siklus II.

\section{Siklus II}

Adapun hasil observasi upaya meningkatkan kemampuan mengenal lambang huruf pada siklus II dapat dilihat pada lembar observasi (data terlampir). Dari hasil pengamatan siklus II dapat diketahui pada aspek mampu menyebutkan lambang huruf pada namanya sendiri, yaitu terdapat 2 anak $(12,5 \%)$ dengan kategori berkembang sesuai harapan, dan 12 anak (75\%) dengan kategori berkembang sangat baik. Dapat menyebutkan lambang huruf terdapat 3 anak $(18,1 \%)$ dengan kategori berkembang sesuai harapan, dan 13 anak $(81,25 \%)$ dengan kategori berkembang sangat baik. Dapat mengulang kembali lambang huruf yang disebutkan oleh guru terdapat, 3 anak $(18,1 \%)$ dengan kategori berkembang sesuai harapan dan13 anak $(81,25 \%)$ dengan kategori berkembang sangat baik. Dapat menyebut kata-kata ayng berlambang huruf sama dengan yang disebutkan guru, terdapat 3 anak $(18,1 \%)$ dengan kategori berkembang sesuai harapan dan 13 anak (81,25\%) dengan kategori berkembang sangat baik.
Berdasarkan hasil pengamatan siklus II, kemampuan mengenal lambang huruf melalui media karpet huruf jika dibangdingkan dengan sebelum melakukan tindakan. Hal ini dapat dilihat pada tabel berikut ini :

Tabel.2

\begin{tabular}{|c|c|c|c|c|c|c|c|}
\hline \multirow{2}{*}{ No } & \multirow{2}{*}{$\begin{array}{l}\text { Aspek yang } \\
\text { diobservasi }\end{array}$} & \multicolumn{4}{|c|}{ Hasil pengamatan } & \multirow{2}{*}{$\begin{array}{l}\text { Jumla } \\
\mathrm{h} \\
\text { yang } \\
\text { tuntas }\end{array}$} & \multirow{2}{*}{$\begin{array}{l}\text { per } \\
\text { sen } \\
\text { tas } \\
\text { e }\end{array}$} \\
\hline & & $\begin{array}{l}\mathrm{B} \\
\mathrm{B}\end{array}$ & $\begin{array}{l}\mathrm{M} \\
\mathrm{B}\end{array}$ & $\begin{array}{l}\text { BS } \\
\mathrm{H}\end{array}$ & $\begin{array}{l}\text { BS } \\
\text { B }\end{array}$ & & \\
\hline 1. & $\begin{array}{l}\text { Dapat } \\
\text { mengulang } \\
\text { kembali } \\
\text { lambang } \\
\text { huruf yang } \\
\text { disebutkan } \\
\text { guru }\end{array}$ & 0 & 2 & 2 & 12 & 14 & $\begin{array}{l}87, \\
5 \%\end{array}$ \\
\hline 2. & $\begin{array}{l}\text { Dapat } \\
\text { menyebutkan } \\
\text { lambang } \\
\text { huruf yang } \\
\text { ditunjukkan } \\
\text { oleh guru }\end{array}$ & 0 & 0 & 3 & 13 & 16 & $\begin{array}{c}100 \\
\%\end{array}$ \\
\hline 3. & $\begin{array}{l}\text { Dapat } \\
\text { menyebutkan } \\
\text { lambang } \\
\text { huruf }\end{array}$ & 0 & 0 & 3 & 13 & 16 & $\begin{array}{c}100 \\
\%\end{array}$ \\
\hline 4. & $\begin{array}{l}\text { Anak mampu } \\
\text { menyebutkan } \\
\text { lambang } \\
\text { huruf pada } \\
\text { namanya } \\
\text { sendiri }\end{array}$ & 0 & 0 & 3 & 13 & 16 & $\begin{array}{c}100 \\
\%\end{array}$ \\
\hline 5. & $\begin{array}{l}\text { Dapat } \\
\text { menyebutkan } \\
\text { kata yang } \\
\text { berlambang } \\
\text { huruf sama } \\
\text { dengan yang } \\
\text { disebutkan } \\
\text { oleh guru }\end{array}$ & 0 & 0 & 3 & 13 & 16 & $\begin{array}{c}100 \\
\%\end{array}$ \\
\hline $\begin{array}{l}\text { Jum } \\
\text { ketı }\end{array}$ & $\begin{array}{l}\text { h rata-rata } \\
\text { asan }\end{array}$ & $\begin{array}{l}0 \\
\%\end{array}$ & $\begin{array}{l}1 \\
2 \\
6 \\
5 \\
\%\end{array}$ & $\begin{array}{l}20 \\
\%\end{array}$ & $\begin{array}{l}80 \\
\%\end{array}$ & 97, & \\
\hline
\end{tabular}

Sumber data penelitian 2017

Hasil pengamatan siklus II berdasarkan tabel 4.3, kemampuan mengenal lambang huruf yaitu : dapat mengulang kembali lambang huruf yang disebutkan guru 87,5\%, dapat menyebutkan lambang huruf yang ditunjukkan oleh guru 100\%, dapat menyebutkan lambang huruf $100 \%$, anak mampu menyebutkan lambang huruf pada namanya sendiri $100 \%$, anak 
mampu menyebutkan kata yang berlamabang huruf sama dengan yang disebutkan oleh guru 100\%.Maka nilai keberhasilan pada siklus II adalah 97,5\%. Kemampuan mengenal lambang huruf pada siklus II meningkat dengan kemampuan anak pada pra siklus.Karena nilai keberhasilan pada siklus II telah mencapai batas minimal pada penelitian, maka penelitian tidak berlanjut pada siklus III.

Hasil penelitian siklus II meningkat jika dibanding dengan siklus I, yaitu kategori berkembang sesuai harapan meningkat $80 \%$ jika dibanding pada siklus I mencapai $68,75 \%$, terdapat peningkatan kemampuan mengenal lambang huruf pada anak disbanding dengan siklus I.

Berdasarkan persentase di atas peneliti menyatakan bahwa media karpet huruf berhasil meningkatkan kemampuan mengenal lambang huruf pada anak kelompok A di TK Mekar Sari Tenggarong Seberang.

\section{Pembahasan Hasil Penelitian}

Kemampuan mengenal lambang huruf akan berkembang jika didukung dengan fasilitas dan kesempatan yang memungkinkan. Orang tua dengan guru harus menyadari segala aspek kemampuan pada anak terutama kemampuan mengenal lambang huruf pada anak.Cara mendidik dan mengasuh anak harus sesuai dengan pribadi dan kecepatan

masing-masing anak.Perkembangan bahasa anak-anak berkembang secara bertahap sehingga memerlukan ketekunan baik dari anak sendiri maupun bagi guru atau orang tua dalam memberikan rangsangan.JohnW.Santrock (2007:357362) mengatakan bahwa perkembangan bahasa dibagi menjadi 3 tahapan.Perkembangan bahasa pada anak masa bayi, perkembangan pada awal kanak-kanak dan masa kanakkanak menengah. Sesuai dengan pendapat tersebut maka peneliti melaksanakan pembelajaran dengan media karpet huruf guna meningkatkan kemampuan mengenal lambang huruf pada anak menyesuaikan dengan usia masa kanak-kanak yang gemar bermain.

$$
\text { Berdasarkan hasil penelitian }
$$
tindakan kelas dengan judul "Meningkatkan kemampuan mengenal lambang huruf pada kelompok A di TK Mekar Sari Tenggarong Seberang Tahun Ajaran 2016/2017” memperoleh hasil melalui tahapan observasi dan tahapan refleksi adalah sebagai berikut :

a. Dari hasil refleksi menunjukkan peningkatan kemampuan mengenal lambang huruf melalui media karpet huruf yang terjadi pada anak kelompok A di TK Mekar Sari dari siklus I ke siklus II menunjukkan kriteria peningkatan kualitas dan mutu, mampu menyebutkan huruf 
pada namanya sendiri, dapat menyebutkan lambang huruf, dapat mengulang kembali lambang huruf yang disebutkan guru dan dapat menunjukkan kata-kata berlambang huruf sma dengan yang disebutkan guru. Dalam penelitian tindakan kelas dari siklus I ke siklus II mengalami peningkatan yang positif baik dari segi kualitas maupun kuantitas nya secara indikator peningkatan pembelajaran yang positif yaitu pada pra siklus kemampuan mengenal lambang huruf pada kelompok A di TK Mekar Sari mencapai nilai rata-rata 0,0\% dengan kategori berkembang sangat baik (BSB). Kemudian setelah melakukan tindakan pada siklus I kemammpuan mengenal lambang huruf di kelompok A pada TK Mekar Sari mencapai nilai ratarata $68,75 \%$ dengan kategori berkembang sesuai harapan (BSH). dan keberhasilan penelitian ini terlihat pada siklus II dengan nilai ketuntasan 97,5\% dengan kategori berkembang sangat baik (BSB). Dengan demikian kemampuan mengenal lambang huruf pada kelompok A di TK Mekar Sari berkembang sangat baik.

b. Peningkatan kemampuan mengenal lambang huruf pada kelompok A di TK Mekar Sari mengalami peningkatan setiap siklus dengan meningkatkan kemampuan mengenal lambang huruf membawa dampak positif pada anak terutama pada aspek bahasa anak. Seperti yang dikatakan (Santrock, 1955:2226) perkembangan kemampuan bahasa sangat dipengaruhi oleh dua factor yaitu factor bawaan dan factor pengasuhan sementara factor pengasuhan mengacu pada lingkungann maka dari itu kemampuan mengenal lambang huruf akan berkembang dengan baik jika diberikan pengajaran dengan benar dan sesuai dengan porsinya.

\section{PENUTUP}

\section{Kesimpulan}

Penelitian tindakan kelas tentang bagaimana meningkatkan kemampuan mengenal lambing huruf pada anak melalui media karpet huruf pada anak didik kelompok A di TK Mekar Sari Tenggarong Seberang Tahun Ajaran 2016/2017 dilaksanakan selama dua siklus yaitu siklus I dan siklus II sebagai berikut :

1. Pembelajaran melalui media karpet huruf dapat meningkatkan kemampuan mengenal lambing huruf pada anak kelompok A di TK Mekar Sari Tenggarong Seberang tahun ajaran 2016/2017. Hal ini 
ditunjukkan oleh nilai rata-rata ketuntasan pencapaikan kemampuan mengenal lambing huruf yang sebelum tindakan dengan nilai rata-rata $0,0 \%$ dengan kategori berkembang sangat baik (BSB) menjadi $68,75 \%$ pada siklus I dan meningkat pada siklus II menjadi 97,5\% dengan kategori berkembang sangat baik (BSB).

2. Langkah-langkah pembelajaran guru dalam mengajar melalui media karpet huruf secara keseluruhan sangat baik. Peneliti selalu member motovasi kepada siswa agar aktif dan bersemangat baik dengan tepuk tangan atau dengan nyanyi. Guru juga telah penguatan yang positif kepada anak yang telah mencoba menggunakan media karpet huruf sesuai dengan aturan dan dengan benar. Disamping itu peneliti mengajar dengan cara member tepukt angan, memberikan pujian secara lisan sehingga anak termotivasi dan merasa dihargai.

\section{Saran}

Berdasarkan hasil-hasilpenelitian
yang diperoleh maka dapat
dikemukakan saran-saran sebagai
berikut:

\section{Bagi Guru}

a. Sebagai pendidik harus mampu merencanakan, melaksanakan dan mengevaluasi program pembelajaran. Ketiga kegiatan pembelajaran itu semua sangat pentingnya dan saling erat hubungannya. Evaluasiakan berguna untuk menentukan langkah-langkah pembelajaran berikutnya jika ditemukan masalah maka akan segera bias dilakukan untuk menentukan tindakan.

b. Sebagai pendidik harus bias menciptakan pembelajaran yang inovatif dengan metode bervariasi sehingga anak tidak merasa jenuh, di dalam mengikuti setiap pembelajaran banyak variasinya, kaya dengan rangsangan agar kemampuan anak dapat berkembang secara optimal.

\section{BagiAnakDidik}

Bagi anak didik diharapkan dapat menggunakan media karpet huruf untuk mengembangkan kemampuan mengenal huruf sesuai dengan potensi yang dimiliki.

\section{Bagi Orang Tua}

a. Memberi motovasi positif kepada anak dan tidak memaksa sesuai keinginan orang tua.

b. Menyadari bahwa kemampuan bahasa anak berkembang sesuai dengan tahap usianya.

c. Menindak lanjuti kegiatan di sekolah menuju kegiatan anak dirumah. 
Jurnal Warna : Jurnal Pendidikan Dan Pembelajaran Anak Usia dini. Maret 2018. Vol 03. No. 01

\section{DAFTAR PUSTAKA}

Arikunto, Suharsimi. 2002." Penelitian Tindakan Kelas". Makalah Pendidikan dan Pelatihan (TOT). Jakarta: Penerbit Rineka Cipta.

Margono, S. 1997. Metodologi Penelitian Pendidikan, Jakarta: Rineka Cipta.

Badudu,Z 1982. Kamus Umum Bahasa Indonesia, Jakarta: Pustaka Seminar Harapan.

Hurlock,E.B. 1995. Perkembangan Anak (edisike -2). Jakarta Erlangga.
Raines, S.C., dan Candy, R.J, 1990.The whole Languange Kindergarten. New York: Colombia University.

Arif, S. Sadiman, dkk. 1990. Media Pendidikan, Pengertian, pengembangan, dan pemanfaatan. Jakarta Rajawali.

Heinich, Mondela,Russel. 1993. Instructional Media, and the new Tecnologies of instruction. (Fourth Edition). New York Macmillan Publising Company.

Nana Sudjanadan Ahmad Rifai.1990.Media Pengajaran.Bandung SinarBaru. 